\title{
A talaj és az éghajlat közötti kapcsolat modellezése
}

\author{
ÁCS FERENC, BREUER HAJNALKA, TARCZAY KLÁRA és \\ DRUCZA MIKLÓS
}

ELTE Meteorológiai Tanszék, Budapest

Az éghajlat az éghajlati rendszerösszetevők: a litoszféra, a pedoszféra, a hidroszféra, a krioszféra, a bioszféra és az atmoszféra kölcsönhatásainak eredménye; e kölcsönhatásokkal létrejött állapotok sokasága. A talaj a litoszféra felszíni, mállott rétege, mely sajátos tulajdonságai miatt a litoszférától elkülönítendő. A talaj alkotta pedoszféra a litoszféra alszférájaként a klímarendszer-összetevők egyike.

$\mathrm{Az}$ éghajlat és a talaj állandó kölcsönhatásban vannak. Ezért az éghajlat talajalakító és a talaj éghajlat-alakító tényező. Geológiai időskálán a talaj és az éghajlat kapcsolatrendszere dinamikus, azaz időben változó (VÁRALLYAY, 1990, 2002). Rövidebb, néhány ezer éves időskálákon e kapcsolat stacionáriusnak vehető a biogeokémiai folyamatok (elsősorban a C- és N-körforgalommal kapcsolatos folyamatok) lassúsága miatt. A talajtan müvelői az éghajlat talajalakító hatását már a XIX. században felismerték. Az éghajlat által formált zonális talajok fogalmát Dokucsajev vezette be; ezzel megalapozta a talajföldrajz tudományát (STEFANOVITS, 1975). E téren hazai viszonylatban Treitz, Ballenegger és Timkó munkássága (STEFANOVITS et al., 1999) emelendő ki. Ugyanakkor a talaj éghajlat módosító hatásáról aligha beszéltek. Az éghajlatkutatók az éghajlati jelenségeket szinte kizárólag a légkörhöz kötötték (SELLERS, 1965). Az éghajlat és a talaj párhuzamos elemzése ugyan szokványos (GOUDIE, 1989; JUSTYÁK \& SZÁsZ, 2001), de a talajnak az éghajlatra gyakorolt hatásával inkább csak érintőlegesen foglalkoztak (SZÁsz, 1963). Az 1980-as évek óta a talaj időjárás és éghajlat módosító szerepe a részletes kutatások tárgya (ROBOCK et al., 1998; HAYDEN, 1998; PIELKE, 1998; WANG \& ELTAHIR, 2000).

A talaj és az éghajlat kapcsolatrendszere néhány száz vagy ezer éves időskálán diagnosztikus modellekkel is tanulmányozható. E modellek közül az ún. bioklíma klasszifikációs módszerek a legegyszerübbek. E modellek biofizikai jellegűek, azaz mellőzik az éghajlat geokémiai tulajdonságainak leírását. Így a többségük csak csapadék- és léghömérséklet-adatokat igényel. Ilyen pl. KÖPPEN (1900) éghajlat rendszerező módszere, mely az éghajlat térbeli eloszlását a növényzet térbeli eloszlása alapján jellemzi. A bioklíma klasszifikációs módszerek közül a Thornthwaiteféle éghajlat rendszerező módszer a legösszetettebb. E módszer a víz, a növényzet

Postai cím: ÁCS FERENC, Eötvös Loránd Tudományegyetem Meteorológiai Tanszék, 1117 Budapest, Pázmány Péter sétány 1/a.E-mail: acs@caesar.elte.hu 
és az éghajlat elemi kapcsolatrendszerén alapszik, figyelembe véve a talaj víztározó képességét és a növényi párolgás alapvető tulajdonságait. THORNTHWAITE (1948) modellje két szempontból is előnyös: részletes klímaklasszifikációra ad lehetőséget valamint könnyen kibővíthetö - elsősorban a talajban lejátszódó folyamatok leírásával. Annak köszönhetően, hogy lehetővé teszi a részletes éghajlat klasszifikációt, ma is elterjedt. MinTZ és SERAFINI (1981), valamint MiNTZ és WALKER (1993) Thornthwaite módszerét alkalmazta a párolgás és a gyökérzóna nedvességtartalmának globális eloszlású becslésére. A módszert gyakorlati célokra is alkalmazták: az Amerikai Egyesült Államokban a gabona nedvességi indexek földrajzi eloszlásának becslésére, vagy Kanadában (Kanadai Klíma Központ) a talajnedvesség heti változásainak feltérképezésére (lásd MINTZ \& WALKER, 1993). Thornthwaite módszerét hazánkban legelőször BACSÓ (1943) alkalmazta. Thornthwaite módszerét alkalmazta még SzESZTAY (1958), KAKAS (1960), SZEPESINÉ (1966) és SzÁSZ (1963). Ezen alkalmazásokban a hasznos vízkészlet állandó volt, a kitüzött célok pedig hidrológiai vonatkozásúak voltak.

Mint ahogy már említettük, Thornthwaite modellje könnyen kibővíthető nemcsak a talajban lejátszódó fizikai, hanem a biogeokémiai folyamatok leírásával is. Mindezek alapján e tanulmány célja a talaj és az éghajlat kapcsolatának elemzése egy Thornthwaite típusú biogeokémiai modell alapján. E biogeokémiai modellt THORNTHWAITE (1948) biofizikai modellje és egy empirikus talajlégzés (talajlégzésnek nevezzük a talajnak a légkörbe történő szén-dioxid kibocsátását) modell (PENG et al., 1998) alkotja. Vizsgálatainkban részletesen elemeztük

- a tényleges párolgás, a talajlégzés és az éghajlat kapcsolatát;

- a különböző éghajlatokhoz tartozó talajlégzés szezonális változásait; és

- az éghajlat érzékenységét a növényzet által felvehető maximális vízmennyiség nagyságára, azaz az ún. hasznos vízkészletre.

Az elemzést globális és lokális skálán végeztük. A globális léptékü elemzést egy az egész Földre vonatkozó adatbázison, míg a lokális léptékü elemzést egy hazai adatbázison hajtottuk végre. Az éghajlati adatokat havi és évi csapadék- és hőmérsékletadatok alkotják. A talaj sajátosságait a talaj fizikai féleségével és hidrofizikai paramétereivel fejeztük ki. Az éghajlatokat igen egyszerủen, a Thornthwaite-i klímaképletekkel jellemeztük. A modell feltételezi az éghajlat és az ökoszisztéma közötti egyensúlyt, ebből eredően az éghajlat és az ökoszisztéma időbeli változatlanságát. Elemzéseinkben a két legfontosabb nyomgázra - a vízgőzre és a szén-dioxidra - összpontosítottunk.

\section{Anyag és módszer}

A Thornthwaite típusú biogeokémiai modell. - Thornthwaite felismerte, hogy a talaj és a növényzet vízforgalma kitünő klímaindikátor. Felismerte azt is, hogy a terület hőellátottsága nem szükségszerüen hőfizikai, hanem hidrofizikai mutatóval is jellemezhető. THORNTHWAITE (1948) vízmérleg modellje igen egyszerü tartálymodell. A tartályt a csapadék telíti, a párolgás üríti. Ha a tartály megtelik, és a csa- 
padék nagyobb, mint a potenciális párolgás, a víz túlfolyik. E túlfolyó víz nem telít más tartályokat, ez képezi a víztöbbletet. De a tartály ki is ürülhet. Üres tartály esetén a párolgás vízhiányt eredményez. Nos, gondoltuk volna, hogy ezen egyszerủ mechanizmus az éghajlat rendszerezésére is alkalmazható! A kategorizálható éghajlattípusok száma 486, így a módszer az éghajlat igen részletes leírását teszi lehetővé.

THORNTHWAITE (1948) az éghajlatokat klímaképletek formájában jellemzi. A klímaképletet 4 betủ alkotja. Az 1. betủ egy nedvességi állapotot jellemző klimatikus index. A 2. betüt a PET potenciális párolgás, a 3. betüt a víztöbblettel és a vízhiánnyal arányos nedvességi és szárazsági index, míg a 4 . betủt a nyári (június, július és augusztus) és évi PET-értékek aránya határozza meg. A klímaképlet első két betüje az évi, míg utolsó két betüje az évszakos vízmérleg-jellemzőkre utal.

A klímaképlet első két betűjének elnevezéseit az 1. táblázat tartalmazza. A klímaképlet 1. betüi A-tól E-ig változnak. Az A-klíma a legnedvesebb, az E-klíma a legszárazabb. Hasonlóképpen, a klímaképlet 2. betüi A'-től E'-ig változnak. Az A'-klíma a legmelegebb, míg az E'-klíma a leghidegebb. Ezek után sejtjük is már, hogy az AA' kombináció (az ábrákon csak A-val van jelölve) a legnedvesebb és a legmelegebb, míg az EA' kombináció (az ábrán csak E-vel van jelölve) a legszárazabb és a legmelegebb kombinációját jelenti. Láthatjuk azt is, hogy az EE' kombináció - ami a legszárazabb és a leghidegebb kombinációja - jelölése szintén hiányzik a helyszüke miatt.

THORNTHWAITE (1948) vízmérleg- és éghajlatmodelljét egy empirikus talajlégzés modellel (PENG et al., 1998) egészítjük ki. Az így kapott Thornthwaite-típusú biogeokémiai modell teljes matematikai leírása BREUER (2004) munkájában található meg.

1. táblázat

A Thornthwaite-i klímaképlet 1. és 2. betüjéhez tartozó elnevezések

\begin{tabular}{|c|l||c|c|}
\hline $\begin{array}{c}\text { A klímaképlet } \\
\text { 1. betüje }\end{array}$ & \multicolumn{1}{c|}{$\begin{array}{c}\text { A vízellátottság } \\
\text { jellemzése }\end{array}$} & $\begin{array}{c}(3) \\
\text { A klímaképlet } \\
\text { 2. betüje }\end{array}$ & $\begin{array}{c}(4) \\
\text { A hőellátottság } \\
\text { jellemzése }\end{array}$ \\
\hline A & a) Perhumid & A' $^{\prime}$ & g) Megatermális \\
\hline B4 & & B4' & \\
B3 & b) Humid & B3' & h) Mezotermális \\
B2 & & B2' $^{\prime}$ & \\
B1 & B1' & C2' & i) Mikrotermális \\
\hline C2 & c) Nedves szubhumid & C1' & j) Tundra \\
\hline C1 & d) Száraz szubhumid & D' $^{\prime}$ & k) Fagyos \\
\hline D & e) Szemiarid & E' $^{\prime}$ &
\end{tabular}


Éghajlati adatok. - Globális és lokális léptékü éghajlati adatokat használtunk. A globális léptékủ adatok a Földre, míg a lokális léptékű adatok Magyarországra vonatkoznak. A globális léptékủ adatokat 230 állomás havi és évi csapadék (P) és hőmérséklet (T) adatai alkotják. Ezek LAMB (1978) könyvében találhatók meg „A World Climatic Table" címü fejezetben. Ezen adatok mellett más klímaadatok is vannak, ezeket tanulmányunkban nem használtuk fel. Az állomások területi eloszlása nem egyenletes, de a Föld összes klímáit lefedik. A 230 állomásból kb. 30 állomás az óriási óceáni térség kisebb szigetein található. Megemlítendő az is, hogy az állomások adatai nem ugyanazon és nem ugyanolyan hosszúságú időszakokra vonatkoznak.



A Föld klímáit jellemző 230 állomás P-T diagramja

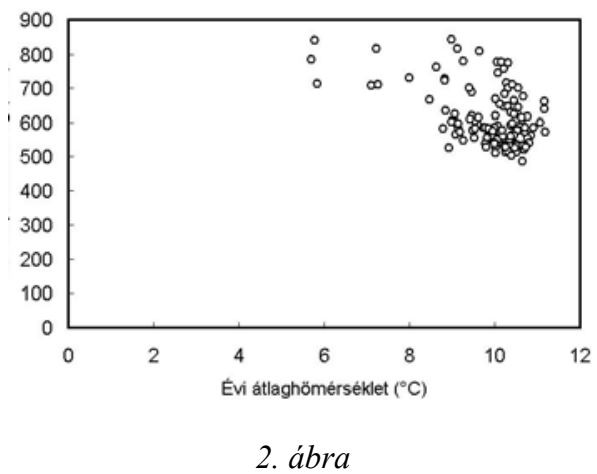

Magyarország klímáit jellemző 125 állomás P-T diagramja

A lokális léptékủ adatokat 125 állomás havi és évi csapadék- és hőmérsékletadatai alkotják. Az adatok az 1901-1950 időszakra vonatkoznak (KAKAS, 1960). A globális léptékủ adatok változatossága értelemszerüen sokkal nagyobb, mint a lokális léptékủeké. Ez jól látható az 1. és 2. ábra összevetése alapján.

A talaj fizikai félesége. - Öt talaj fizikai féleséget különböztettünk meg: homok, homokos vályog, vályog, agyagos vályog és agyag. Egyes állomások területén elöfordult még jég, szikla és tőzeg, illetve kotu. Ezen esetekben a felvehető vízmenynyiséget egységesen $100 \mathrm{~mm}$-ben állapítottuk meg. Globális léptékben a talajok fizikai féleségét ZOBLER (1986) alapján állapítottuk meg. A magyarországi talajok fizikai féleségét az MTA TAKI GIS Laboratóriuma bocsátotta rendelkezésünkre.

A numerikus vizsgálatok. - A numerikus vizsgálatokban három esetet különböztettünk meg. Az esetekben szereplö feltételek a hasznos vízkészlet nagyságát határozzák meg. Az 1. eset az ún. referencia eset. Ekkor a hasznos vízkészlet 100 mm függetlenül a textúrától és az esetekben leírt feltételektől. A 2. és 3. esetben a hasznos vízkészlet függ a textúrától és a $\Psi(\Theta)$ víztartóképesség-függvény alakjától. Globális léptékben a $\Psi(\Theta)$ számítására ClAPP és HORNBERGER (1978) parametrizációját és COSBY (1984) paramétereit, míg lokális léptékben VAN GENUCHTEN (1980) parametrizációját és NEMES (2003) paramétereit alkalmaztuk. 
A 2. esetben a hasznos vízkészlet a $\mathrm{pF}=2,5-4,2$ értéktartománnyal adott $\left(\mathrm{pF}=\log _{10}\right.$ $(|\Psi(\Theta)| \mathrm{cm}$ vízoszlopmagasság)). A 3. esetben a $\Psi(\Theta)$-t ugyanúgy számítjuk, mint a 2. esetben, de a hasznos vízkészlet a $\mathrm{pF}=1,7$ (WösTEN et al., 1999) és 4,2 értéktartománnyal definiált.

Megemlítendő, hogy a hasznos vízkészlet homok esetén a legkisebb, míg vályog esetén a legnagyobb és ezen értékek jelentősen eltérnek a referenciának választott $100 \mathrm{~mm}$-töl.

\section{Modellvizsgálati eredmények}

A talaj és az éghajlat kapcsolatát leginkább a talaj és a légkör közötti víz- és szén-dioxid-áramok nagysága és dinamikája határozza meg. Ezért részletesen elemeztük

- az éghajlat, a tényleges párolgás és a talajlégzés évi jellemzőinek kapcsolatát mind globális, mind lokális léptékben;

- az éghajlati tényezőknek a talajlégzés szezonális változásaira kifejtett hatását mind globális, mind lokális léptékben; és

- az éghajlat érzékenységét a hasznos vízkészlet nagyságára.

\section{Az éghajlat, a tényleges párolgás és a talajlégzés évi jellemzöi közötti kapcsolat}

A tényleges párolgás (ET) évi összegének klímaképletek szerinti változását a 2. futtatás esetén globális léptékben a 3A. ábrán mutatjuk be. Az ábrán az adott éghajlatokhoz tartozó pontok átlagértékeket jelölnek. Kihangsúlyozandó, hogy az adott klímaképlethez tartozó talajok fizikai féleségei különböznek. Egyes pontoknál kis oszlopocskák láthatók, melyeknek felső pontja a maximális, míg alsó pontja a minimális értéket mutatja.

Az ET víz- és hőellátottságtól való függése nyilvánvaló. Az igen nedves és meleg klímákban (AA'-B1A') az ET átlagok $1200 \mathrm{~kg} \cdot \mathrm{m}^{-2} \cdot \mathrm{e}^{-1}$ érték körüliek. A B1A'-tól a DA'-ig (azaz a meleg és nedves klímáktól a meleg és félszáraz klímá-

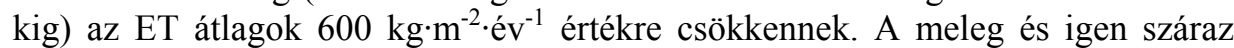
klímákban (EA') az ET átlagok $200 \mathrm{~kg} \cdot \mathrm{m}^{-2} \cdot \mathrm{év}^{-1}$ érték körüliek. Tehát az igen száraz és meleg klímák (EA') ET átlaga kb. 1/6-a az igen nedves és meleg klímák (AA') ET átlagának. Nézzük meg most közelebbről a hőellátottság hatását! Láthattuk, hogy az AA' klímában az ET átlag $1200 \mathrm{~kg} \cdot \mathrm{m}^{-2} \cdot \mathrm{év}^{-1}$ érték körüli. Az AD' (azaz a nedves és hideg) klímában, az ET átlag már $350 \mathrm{~kg} \cdot \mathrm{m}^{-2} \cdot \mathrm{e}^{-1} \mathrm{körüli}$. Hasonlóképpen, az igen száraz és meleg klímákban (EA') az ET átlag $200 \mathrm{~kg} \cdot \mathrm{m}^{-2} \cdot \mathrm{e}^{-1}$ érték körüli, míg az igen száraz és hideg klímákban ez az érték $100 \mathrm{~kg} \cdot \mathrm{m}^{-2} \cdot \mathrm{e}^{-1}$. Tehát az igen nedves klímákban az ET a hőellátottság csökkenésére valamelyest erősebben csökken, mint az igen száraz klímákban. Láthatjuk, hogy az ET csökken mind a víz- mind a hőellátottság csökkenésével. Egy nedvességi kategórián belül az ET csökkenése a hőellátottság csökkenésével lineárisnak vehető. Az ET változása a klímaképletek függvényében fürészfüggvényszerünek vehető. 


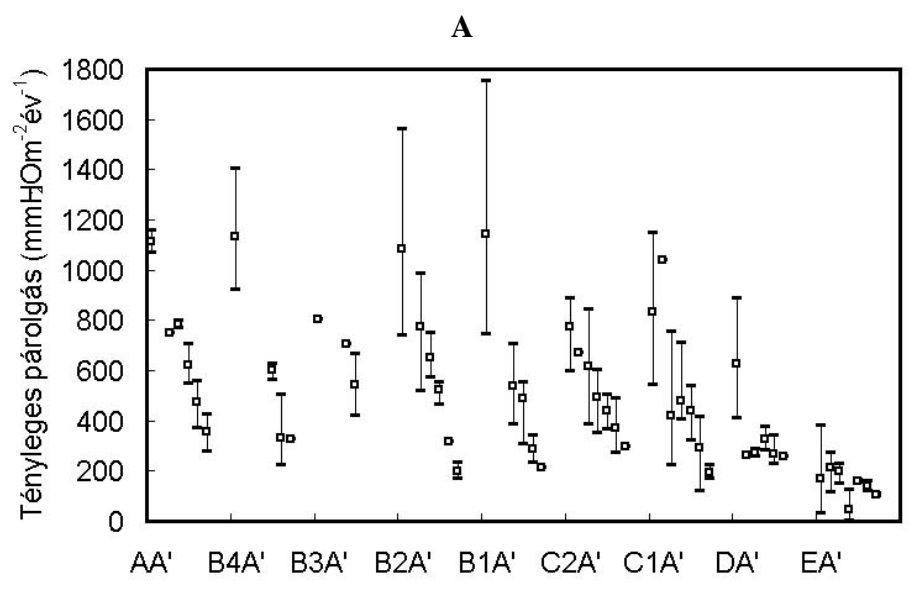

B



3. ábra

A tényleges párolgás évi összege és a Thornthwaite-i kódok (A), ill. az évi talajlégzés és a Thornthwaite-i kódok (B) kapcsolata a 2. futtatás esetén

Az évi talajlégzés (SR) klímaképletek szerinti változását a 2. futtatás esetén globális léptékben a 3B. ábra szemlélteti. A függés ugyanolyan, mint az előbbi esetben. A változások mértéke is (mennyivel csökken az SR átlaga a víz- vagy a hőellátottság csökkenésével) nagyon hasonló, de van egy alapvető különbség. A vízátvitel három nagyságrenddel nagyobb, mint a $\mathrm{CO}_{2}$ átvitele. Ugyanis, a víz mennyiségét kg-ban, míg a szén-dioxidban levő szén mennyiségét g-ban fejezzük ki. Láthatjuk azt is, hogy ebben az esetben az átlagtól vett eltérések valamelyest kisebbek, mint az előbbi esetben.

Magyarország éghajlata a Thornthwaite-i kódok formájában kifejezve a 4A. ábrán látható. A klímaképletet ezúttal mindössze két betủ alkotja: az 1. és a 3. betü, ezek a nedvességi viszonyokra utalnak. A 2. betű B1', azaz a terület hőellátottsága 
mezotermális, és a térben állandó. A 4. betü az esetek többségében b3' (a nyári és az évi potenciális párolgás aránya $52-56 \%$ között van); a hegyes és dombos területek hüvösebb és a nedvesebb övezeteiben esetenként b2' (56-62\% közötti arány) is lehet. A térkép jól tükrözi Magyarország éghajlati körzeteinek térbeli eloszlását (PÉCZELY, 1979): a mérsékelten nedves Dunántúlt és az Északi-középhegységet, valamint a szárazabb Alföldet és Kisalföldet. A Mecsek, a Drávamenti-síkság, a Zalai-dombság, a Soproni- és Kőszegi-hegység, a Bakony térsége, a Visegrádihegység, a Börzsöny-, Mátra-, Bükk-hegységek B1, B2, esetenként B3 klímával (a B3 klíma Magyarország legnedvesebb klímája) is rendelkeznek. E klímák többségében még szezonálisan sem fordul elő a vízhiány. A Somogyi-dombság, a Mosoni-síkság és Bakonyalja, a Borsodi-dombság és a Zempléni-hegység C2s klímájú, azaz nedves szubhumid mérsékelt nyári vízhiánnyal. A Kisalföld, a Vértes, a Velencei-hegység a Cserhát, a Kiskunság és a Nyírség C1s klímájú, azaz száraz szubhumid mérsékelt téli víztöbblettel. Az Alföld és a Dunántúl egy kis része C1d klímájú, azaz száraz szubhumid víztöbblet nélkül. Látható, hogy Magyarország éghajlatát döntően a domborzat befolyásolja. Egyébként országunk legnagyobb éghajlati gradiensei (a klímatípusok változása kis térségben) a Dunakanyar környékén vannak. Ott 10-20 km-es körzetben megtalálható a legszárazabb C1d éghajlat (Szentendrei sziget) mellet a $\mathrm{C} 1 \mathrm{~s}$, a $\mathrm{C} 2 \mathrm{~s}$, valamint a már egyértelmüen nedvesnek mondható B1r éghajlat is.

A tényleges párolgás évi összegének területi eloszlása Magyarországon a 4B. ábrán látható. A párolgás $400-600 \mathrm{~kg} \cdot \mathrm{m}^{-2} \cdot e^{-1}{ }^{-1}$ érékek között változik. Összevetve a 4A. és 4B. ábrákat, láthatjuk, hogy a két területi eloszlás nagyon hasonló. Az ET 550-600 $\mathrm{kg} \cdot \mathrm{m}^{-2} \cdot \mathrm{é}^{-1}$ a nedves B1-es klímájú Mecsekben, a Drávamenti-síkságon, a Zalai-dombságon, a Soproni- és Köszegi-hegységben és a Bakony térségében. A Börzsönyben, Mátrában, Bükkben (ezek B klímájú területek) és a Zemplénihegységben (ez C klímájú terület) az ET $500-550 \mathrm{~kg} \cdot \mathrm{m}^{-2} \cdot \mathrm{e}^{-1}$. Ezen esetekben az ET értékét alapvetően a domborzat határozza meg. Az ET nagyságát azonban a domborzati tényezők mellett a talaj fizikai félesége is meghatározza. Ez egyértelmüen látható a homok esetében. Az összefüggőbb homokos területek felett (BelsöSomogy, Kiskunság, Nyírség és Gödöllői-dombság) az ET észrevehetően kisebb a nem homokos területek ET értékénél. A homokos Kiskunságban és Nyírségben az ET mindössze $400 \mathrm{~kg} \cdot \mathrm{m}^{-2} \cdot$ év $^{-1}$ körüli. A homok kis víztartó képességének hatása a klímaképletben is megmutatkozik. E helyeken a klímaképlet 2 . betüje többnyire „s”, ami a C1-es éghajlat esetében mérsékelt téli víztöbbletet (a kis víztározó képességü talajok télen könnyebben töltődnek fel vízzel), míg a C2-es éghajlat esetében mérsékelt nyári vízhiányt (a kis víztározó képességü talajok nyáron könnyebben veszítik el a vizet) jelent.

A talajlégzés évi összegének területi eloszlását Magyarországon a 4C. ábra szemlélteti. A talajlégzés $380-470 \mathrm{~g} \mathrm{C} \cdot \mathrm{m}^{-2} \cdot \mathrm{év}^{-1}$ értékek között változik, ami igen kis határérték-tartomány. Ennek ellenére az ET és az SR területi eloszlása nagyon hasonló. Az SR esetében is látható a domborzat és a talaj fizikai féleségének együttes hatása. A Mecsekben, a Drávamenti-síkságon, a Zalai-dombságon és a Bakony 
A



$\mathrm{Cl}, \mathrm{d}$ Száraz szubhumid, kevés vagy elhanyagolható vizzöbblet $\mathrm{B} 1, \mathrm{~s}$ Humid, közepes nyári vizhiány

\begin{tabular}{|c|c|c|}
\hline $\mathrm{Cl}, \mathrm{s}$ & nid, közepes téli viztöbblet & \begin{tabular}{|l|l}
$\mathrm{B} 1, \mathrm{r}$ & Humid, kevès vagy elhanyagollhato vizhiány \\
\end{tabular} \\
\hline $\mathrm{C} 2, \mathrm{~s}$ & Nedves szubhumid, közepes nyari vizhiany & \begin{tabular}{c|c}
$\mathrm{B} 2, \mathrm{r}$ & Humid, kevés vagy elhanyallhato vizhiany
\end{tabular} \\
\hline C & ható vizhiány & gy elhanyagollhato \\
\hline
\end{tabular}

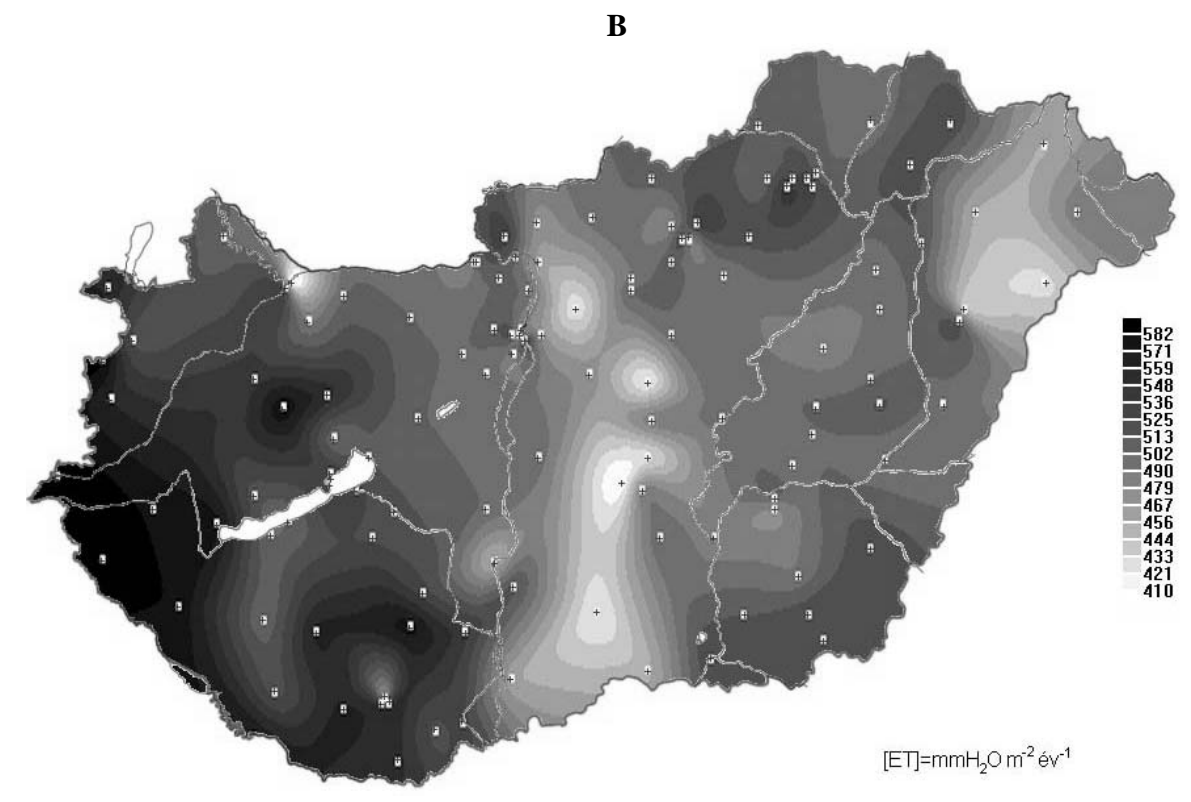






Magyarország éghajlata a Thornthwaite-i kódok alapján (A), ill. a tényleges párolgás (B) és talajlégzés $(\mathrm{C})$ területi eloszlása a 2 . futtatás esetén

térségében a legnagyobb (470 $\mathrm{g} \mathrm{C} \cdot \mathrm{m}^{-2} \cdot \mathrm{e}^{-1}$ körüli). A Mátrában, Bükkben és Csereháton az SR értékek már $400 \mathrm{~g} \mathrm{C} \cdot \mathrm{m}^{-2} \cdot \mathrm{e}^{-1}$ körüliek. Itt az alacsonyabb hőmérsékletek talajlégzést csökkentő hatása érvényesül. Látható az is, hogy a homokos területek felett az SR igen kicsi: a Kiskunságban és Nyírségben $400 \mathrm{~g} \mathrm{C} \cdot \mathrm{m}^{-2} \cdot e^{-1}{ }^{-1}$ alattiak is lehetnek; Belsö-Somogyban valamelyest nagyobbak $\left(440 \mathrm{~g} \mathrm{C} \cdot \mathrm{m}^{-2} \cdot \mathrm{e}^{-1} \mathrm{e}^{-1}\right.$ ék körüliek). A domborzat és a homok együttes hatása a Gödöllői-dombságon és a Zempléni-hegységen figyelhető meg.

\section{A talajlégzés szezonális változásai}

Eddig az éghajlat és a talaj kapcsolatát meghatározó anyagáramok (vízgőz és szén-dioxid) évi karakterisztikáit elemeztük. Rátérünk a talajlégzés és az éghajlat kapcsolata szezonális karakterisztikáinak elemzésére mind globális, mind lokális léptékben. A hőellátottság hatását a talajlégzés szezonális változásaira globális léptékben különböző nedvességủ klímákban az 5. ábra szemlélteti. A hőellátottság talajlégzésre kifejtett hatását az igen nedves klímákban (A klíma) az 5A. ábrán mutatjuk be. A nedves, meleg klímákban (AA' klíma) a talajlégzés havi értékei elérik a $150 \mathrm{~g} \mathrm{C}^{-2} \cdot \mathrm{m}^{-2}$ hónap ${ }^{-1}$ értéket is. Ezzel szemben a nedves és mérsékelten hideg klímákban (AC1' klíma) a havi értékek $50 \mathrm{~g} \mathrm{C} \cdot \mathrm{m}^{-2} \cdot$ hónap $^{-1}$ alatt vannak. A hőellá-tottság hatása az igen száraz klímákban az $5 \mathrm{~B}$. ábrán látható. Ebben az esetben a különbségek kicsik. 
A

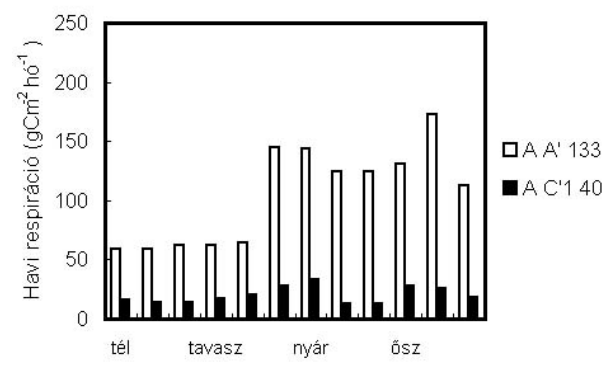

B

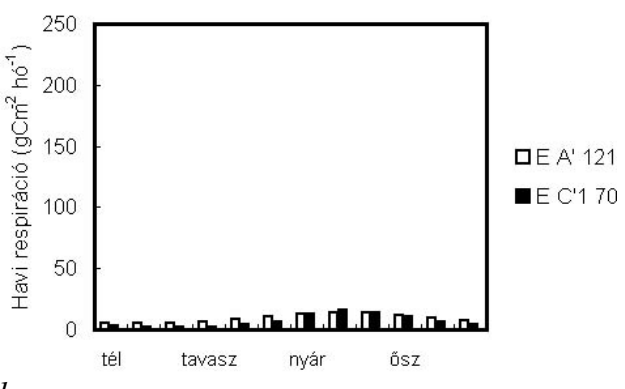

5. ábra

A hőellátottság hatása a talajlégzés évi menetére nedves (A) és száraz (B) klímákban

A vízellátottság hatása a talajlégzés szezonális változásaira globális léptékben különböző hőellátottságú klímákban a 6. ábrán látható. A nedvesség hatását az igen jó hőellátottsági viszonyokban a $6 \mathrm{~A}$. ábra szemlélteti. Mint ahogy láthattuk, az igen nedves és meleg klímákban (AA') a talajlégzés maximális havi értékei 170 g $\quad \mathrm{C} \cdot \mathrm{m}^{-2} \cdot$ hónap $^{-1}$ körüliek. Ezzel szemben az igen száraz és meleg klímákban (EA') e maximális értékek $50 \mathrm{~g} \mathrm{C} \cdot \mathrm{m}^{-2} \cdot$ hónap $^{-1}$ körüliek. A nedvesség hatását a mérsékelten hüvös klímákban (C1') a 6B. ábra mutatja be. Ebben az esetben a vízellátottság okozta különbségek már csak $10-30 \mathrm{~g} \mathrm{C} \cdot \mathrm{m}^{-2} \cdot h$ hónap $^{-1}$ érték körüliek.

Látható tehát, hogy a respiráció szezonális változásait mind a hö-, mind a vízellátottság jelentősen meghatározza.

Thornthwaite klímaklasszifikációjában a klíma szezonális változásait is lehetséges jellemezni a klímaképlet 3 . betủjével. A 3 . betủ hatásának számszerüsítése feltételezi az első két betűvel jellemzett klímák állandóságát, vagy - ha ez nem lehetséges - a klímák hasonlóságát. Ilyen értelemben hasonlítottuk össze az erős téli és az erős nyári vízhiány (w2/s2) valamint a gyenge téli és a gyenge nyári vízhiány (w/s) talajlégzésre kifejtett hatásait. E hatásokat globális léptékben a 7. ábrán elemezhetjük.

A

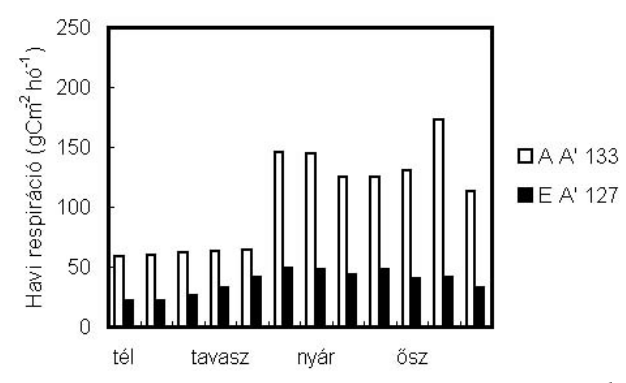

B

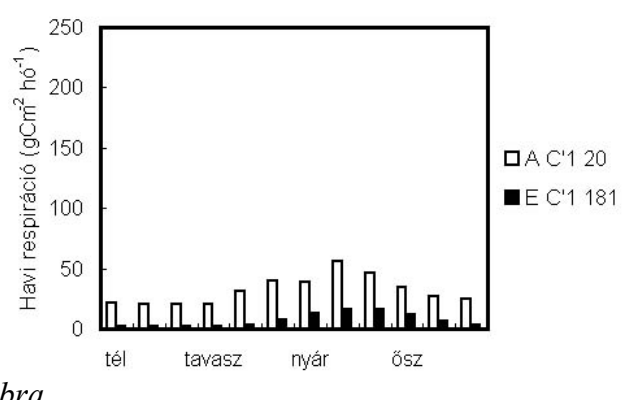

6. ábra

A vízellátottság hatása a talajlégzés évi menetére meleg (A) és hüvös (B) klímákban

A 

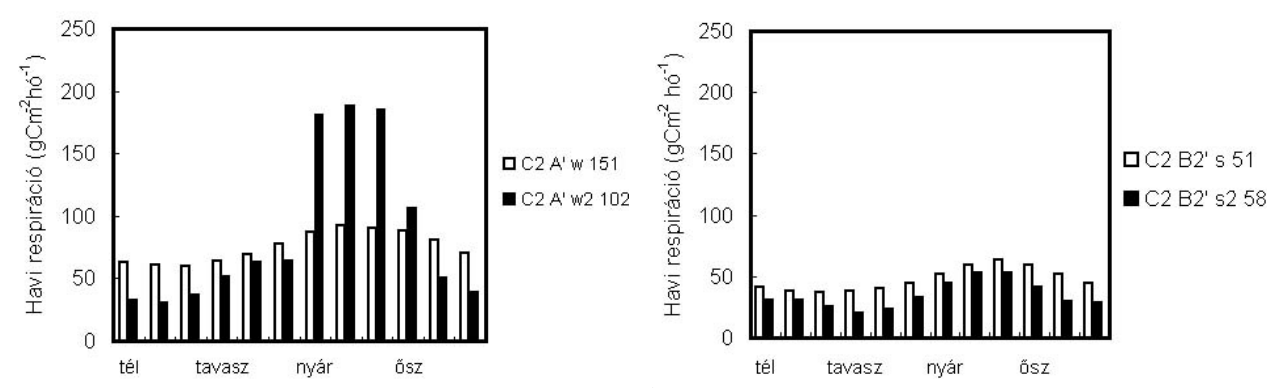

7. ábra

A téli $\left(\mathrm{w} / \mathrm{w}_{2}\right)(\mathrm{A})$ és a nyári $\left(\mathrm{s} / \mathrm{s}_{2}\right)(\mathrm{B})$ vízhiány típusok hatása a respiráció évi menetére

A 7A. ábra az erős téli vízhiány és a gyenge téli vízhiány talajlégzésre kifejtett hatását szemlélteti. Az adott esetben a kétbetüs Thornthwaite-i klímaképlet: $\mathrm{C} 2 \mathrm{~A}$ '. Láthatjuk, hogy az erős téli vízhiány esetén a nyári talajlégzés eléri a $180 \mathrm{~g} \mathrm{C} \cdot \mathrm{m}^{-2}$. hónap ${ }^{-1}$ értéket is, míg a gyenge téli vízhiány esetén a nyári értékek $100 \mathrm{~g} \mathrm{C}$. $\mathrm{m}^{-2} \cdot$ hónap $^{-1}$ alatt vannak. Szembetünő az is, hogy a téli vízhiány mértéke leginkább nyáron fejti ki hatását. A nyári vízhiány talajlégzésre kifejtett hatását a 7B. ábra szemlélteti. Ebben az esetben a kétbetüs Thornthwaite-i klímaképlet: C2B2'. Láthatjuk, hogy az erős és a gyenge nyári vízhiány esetében kapott talajlégzés értékek közötti eltérések kicsik.

Mint ahogy már láthattuk az évi karakterisztikákkal kapcsolatban, Magyarországon a vízháztartás és ezen keresztül a felszín közeli éghajlat is erösen domborzatfüggő. A továbbiakban azt vizsgáljuk, hogy Magyarország vízellátottsága hogyan és milyen mértékben határozza meg a talajlégzés szezonális változásait. A vízellátottság hatását a talajlégzés szezonális változásaira Magyarországon a $8 \mathrm{~A}$. és $8 \mathrm{~B}$. ábra szemlélteti. A vízellátottságra a Thornthwaite-i klímaképlet 1. és 3. betüi utalnak. A C2s klíma: nedves szubhumid klíma, mérsékelt nyári vízhiánnyal. Ezzel szemben a C1s klíma: száraz szubhumid klíma, mérsékelt téli víztöbblettel. A két esetben a talajlégzés szezonális változása különbözik, de nem jelentősen. Ugyanez állapítható meg a B2r és a C2r klímákkal kapcsolatban. E szezonális változásokat a $8 \mathrm{~B}$. ábrán láthatjuk.

A talajlégzés szezonális változásait nemcsak az évi vízellátottság nagysága, hanem a vízellátottság szezonális változásai is meghatározhatják. E kapcsolat egy magyarországi példán a $8 \mathrm{C}$. ábrán látható. A C1s klíma mérsékelt téli víztöbbletet, míg a C1d klíma kicsi vagy nem létező víztöbbletet jelent. Láthatjuk, hogy a két esetben a talajlégzés szezonális változásai csak kissé különböznek.

\section{Az éghajlat érzékenysége a hasznos vizkészlet nagyságára}

A hasznos vízkészlet $\left(\Theta_{\max }=\theta_{\mathrm{f}}-\theta_{\mathrm{w}}\right.$ ) fontos hidrofizikai paraméter, mert meghatározza a tényleges párolgást, a vízhiányt, a víztöbbletet és a talajban tárolt vízmennyiséget. Így a $\Theta_{\max }$ hat bizonyos mértékig az $\mathrm{I}_{\mathrm{m}}$ nedvességi indexre is, azaz a 

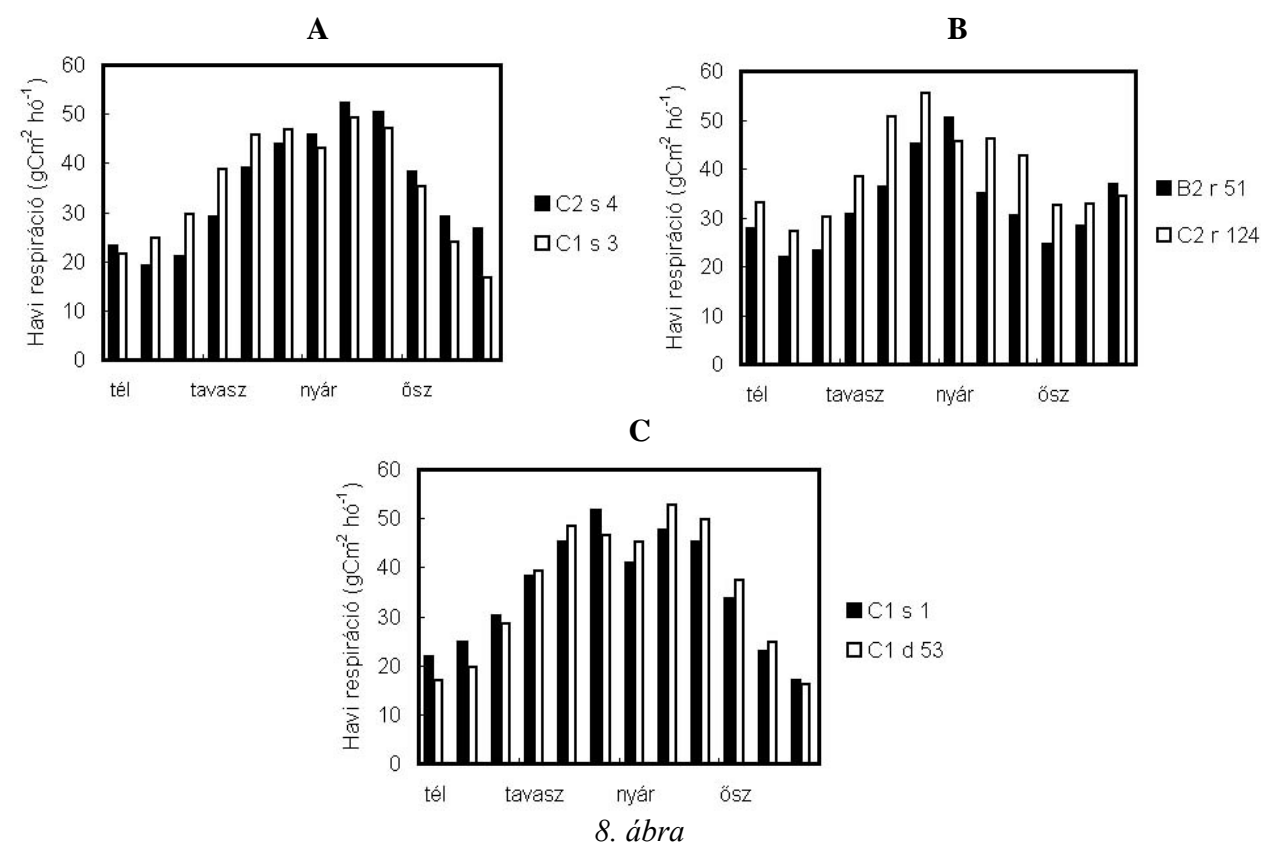

A vízellátottság hatása a talajlégzés évi menetére a $C 2$ és $C 1$ (A), a B2 és $C 2$ (B),

ill. C1s és C1d (C) klímákban

Thornthwaite-i klímaképlet 1. betủjére. Mindezek alapján láthatjuk, hogy a $\Theta_{\max }$ paraméter - bizonyos mértékig - klímaalakitó tényező is. A hatás mértékét globális léptékben a 2. táblázatban láthatjuk. A hatás nem nagy, de mégis szembetűnő. Látható az is, hogy e klímaképlet változások a referencia esethez képest a 3. futtatás esetén nagyobbak, mint a 2 . futtatás esetén. A klímaképletek térbeli változásairól globális léptékben, pl. Kelet-Ázsia példáján, betekintést nyerhetünk a 9A. (referencia eset) és 9B. (3. futtatás) ábrák összehasonlításával.

\section{2. táblázat}

A klímák száma a Thornthwaite-i kód 1. betüje szerint a 3 futtatás esetén

\begin{tabular}{|c|c|c|c|}
\hline $\begin{array}{c}(1) \\
\text { A klímaképlet 1. } \\
\text { betüje }\end{array}$ & $\begin{array}{c}(2) \\
\text { 1. eset }\end{array}$ & 2. eset & 3. eset \\
\hline A & 26 & 26 & 25 \\
B4 & 13 & 13 & 11 \\
B3 & 9 & 9 & 11 \\
B2 & 25 & 23 & 21 \\
B1 & 23 & 24 & 20 \\
C2 & 43 & 42 & 40 \\
C1 & 35 & 37 & 41 \\
D & 23 & 23 & 28 \\
E & 33 & 33 & 33 \\
\hline
\end{tabular}




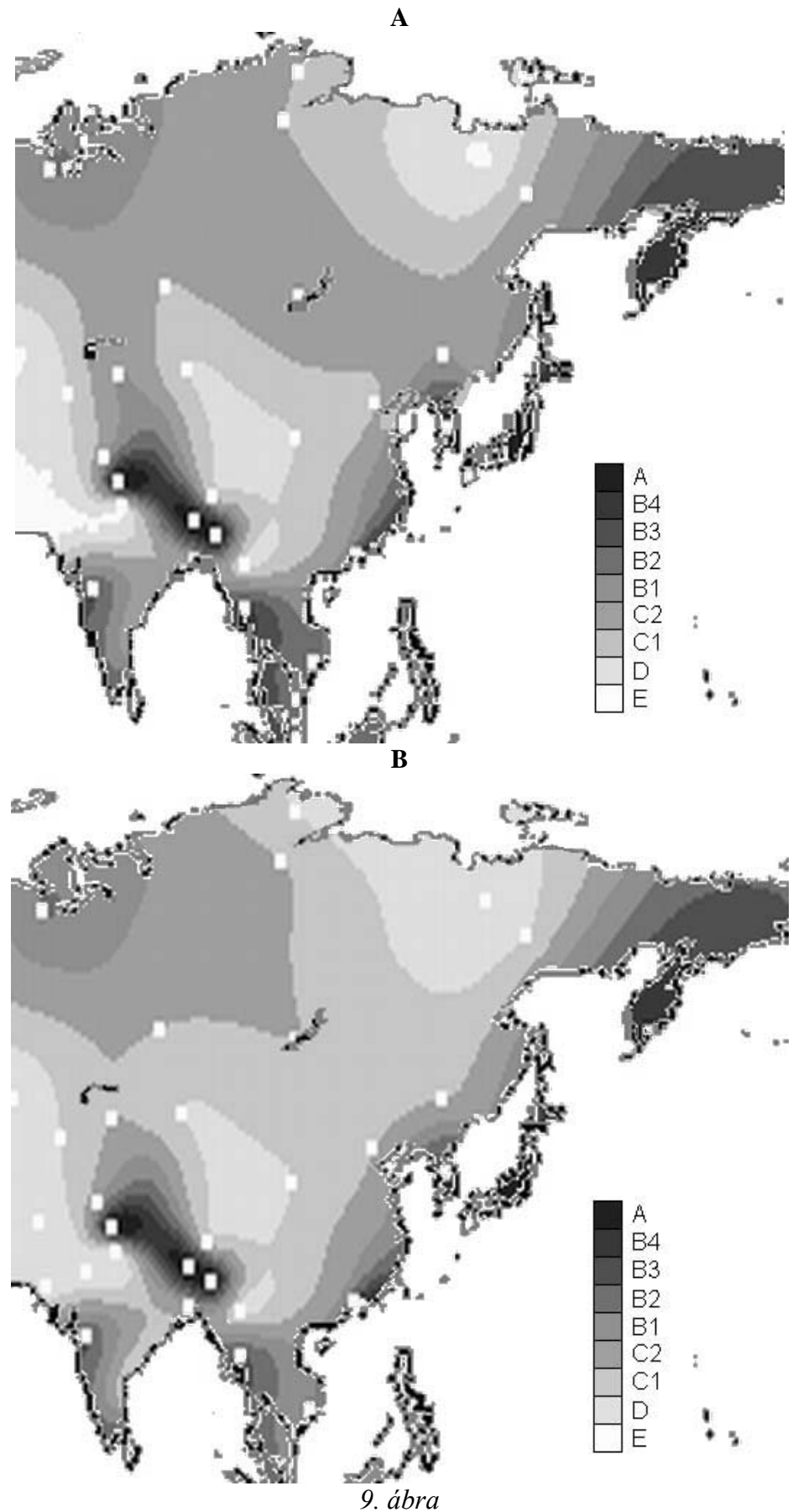

A Thornthwaite-i klímaképlet 1. betüjének térbeli eloszlása Kelet-Ázsiában az 1. (A) és 3. (B) futtatás esetén 
Láthatjuk, hogy az eltérések igen nagyok a Bajkál-tó és a Koreai-félsziget között elterülő mandzsúriai és az Amur folyóval övezte területeken. Az eltérések szintén jelentősek a Szihote-Alin térségében, ami a Szahalin és a Hokkaidó szigetekkel szemben elhelyezkedő ázsiai tengerparti szakasz.

A Thornthwaite-i klímaképlet térbeli eloszlásának érzékenységét a hasznos vízkészlet nagyságára Magyarország esetén is elemeztük. A klímaképlet térbeli eloszlása Magyarországon a referencia esetben a 10. ábrán látható. A 4A. (2. eset) és a 10. ábra (1. eset) összehasonlítása alapján a következőket mondhatjuk: lokális léptékben a hasznos vízkészlet változásaira a klímaképlet 1 . betűje mellett a klímaképlet 3. betüje is megváltozhat, azaz az éghajlat évi karakterisztikái mellett az éghajlat szezonális karakterisztikái is megváltozhatnak. A referencia esetben C1d éghajlat csak a Körösök környékén van és területe nagyon kicsi. Az Alföld referencia esetre vonatkozó C1s éghajlata (10. ábra) a 2. futtatás esetén C1d éghajlatúvá alakul (4A. ábra), kivéve a Bácskai lösz és a Kiskunság homokos térségét. Megemlítendő az is, hogy e C1d éghajlatú terület érintve a Hernád völgyét és a Cserehát területét felnyúlik egészen a szlovák határig. Látható az is, hogy a $\Theta_{\max }$ változásaira a Szentendrei sziget éghajlata C1s-röl C1d-re módosul. Továbbá: A referencia esetben a C2s klíma a Dunántúltól kezdve a Vértesen, Dunakanyaron, Cserháton, Csereháton és a Zempléni-hegységen át, egészen a Nyírségig összefüggő területet alkot.

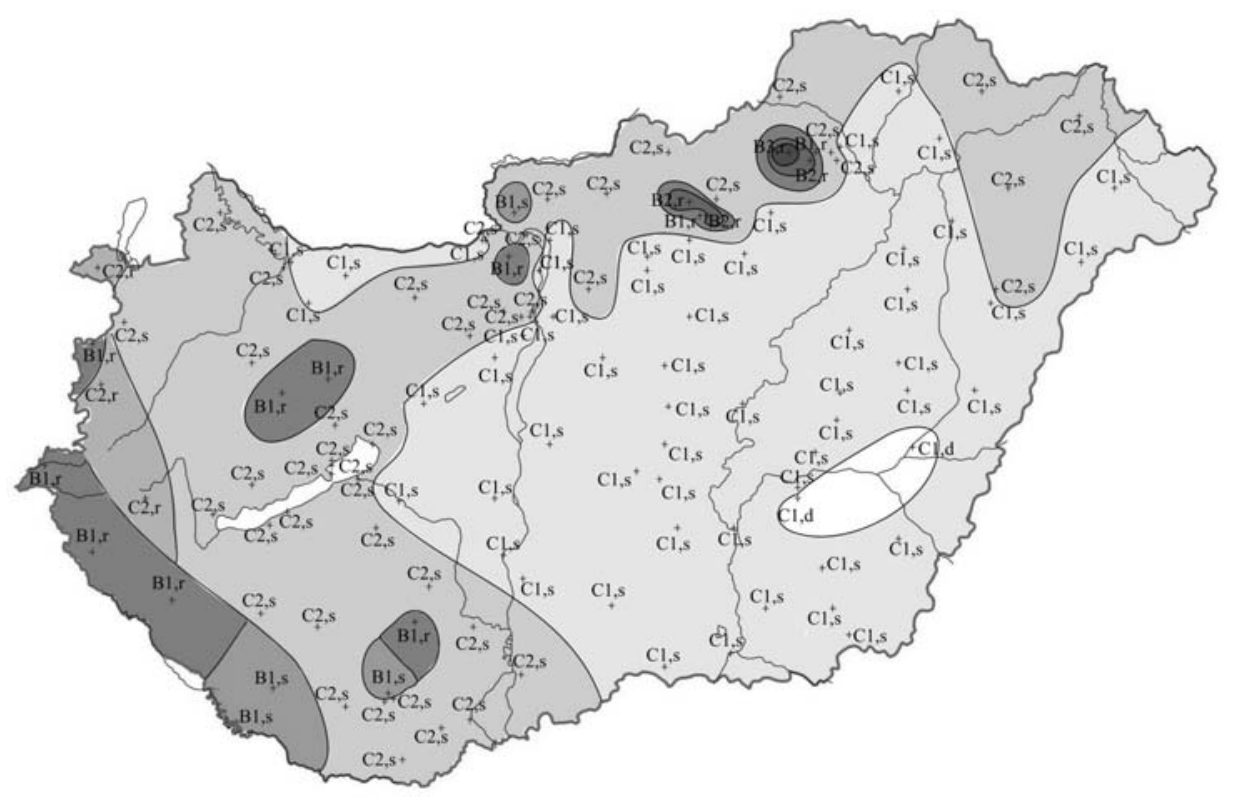

10. ábra

Magyarország klímája a Thornthwaite-i kódok alapján az 1. futtatás esetén 
A 2. futtatás esetén ezen összefüggő C2s klímájú terület felszakadozik és sok helyen C1s klímájú területté alakul. Ezt tapasztalhatjuk a Vértes, Gerecse, és Cserhát esetében. Végül megemlítendő az is, hogy a referencia esetben a C2r klímájú területek nem érik el, míg a 2. futtatás esetén elérik a Balaton partját. Summázva megállapíthatjuk, hogy Magyarországon a $\Theta_{\max }$ változásaira a Thornthwaite-i klímaképlet 3. betüje a legérzékenyebb, azaz a hasznos vízkészlet változásaira a vízmérleg és az éghajlat szezonális karakterisztikái a legérzékenyebbek.

\section{Összefoglalás}

E tanulmányban a talaj és az éghajlat közötti kapcsolatot elemeztük. Az elemzést egy Thornthwaite-típusú biogeokémiai modell alapján végeztük, amelyet THORNTHWAITE (1948) biofizikai modellje és egy empirikus talajlégzés modell (PENG et al., 1998) alkotja. A modell feltételezi az éghajlat, a növényzet és a talaj közötti egyensúlyt, ebből eredően az éghajlat, a növényzet és a talaj időbeli változatlanságát. Számításainkat globális (egy az egész Földre vonatkozó adatbázis) és lokális (egy hazai adatbázis) léptékủ éghajlati adatokkal végeztük. Vizsgálatainkban részletesen elemeztük az éghajlat, a tényleges párolgás és a talajlégzés évi és szezonális karakterisztikáinak egymás közötti kapcsolatát. Eredményeink közül a legfontosabbak a következök:

- Az éghajlat, a tényleges párolgás és a talajlégzés évi karakterisztikáinak területi mintázatai között egyértelmü kapcsolat fedezhető fel mind globális, mind lokális léptékben.

- A tényleges párolgás $\left(100-1000 \mathrm{~kg} \mathrm{H}_{2} \mathrm{O} \cdot \mathrm{m}^{-2} \cdot \mathrm{é}^{-1}\right)$ átlagban három nagyságrenddel nagyobb, mint a hozzátartozó talajlégzés $\left(100-1000 \mathrm{~g} \mathrm{C}^{-2} \cdot \mathrm{m}^{-2} \mathrm{e}^{-1}\right)$. A tényleges párolgás értékek összemérhetőek a talajban tárolt vízmennyiséggel. Ezzel szemben a talajlégzés értékek nem mérhetőek össze a talajban tárolt szénmennyiség értékekkel.

- A talajlégzés szezonális változásait döntően meghatározza az adott éghajlathoz tartozó évi hő- és vízellátottság. Mivel Magyarországon az évi hő- és vízellátottság értékek között nincsenek nagy különbségek, a talajlégzés különböző klímatípusokhoz tartozó szezonális változásai között az eltérések szintén kicsik.

Elemzéseinkben azt is megmutattuk, hogy a hasznos vízkészlet alapvető fontosságú talajparaméter. Változásai módosítják nemcsak a talajból kibocsátott vízgőz- és szén-dioxid-áramokat, hanem az éghajlatot is mind globális, mind lokális léptékben. Ezek alapján nyilvánvaló, hogy az éghajlat modellezésében a talaj hasznos vízkészletének számításba vétele nélkülözhetetlen.

Elemzéseinkben kizárólag a tényleges párolgásra és a talajlégzésre összpontosítottunk, ugyanis a talaj és az éghajlat szempontjából e két anyagáram a legfontosabb. A talaj szempontjából azért, mert a víz és a szén-dioxid, valamint a vele kapcsolatos szén meghatározza a talaj fizikai, kémiai és biológiai tulajdonságait; az éghajlat szempontjából pedig azért, mert a vízgőz és a szén-dioxid a légkör két legfontosabb üvegházhatású gáza. 
Kulcsszavak: talaj, éghajlat, modellezés, Thornthwait típusú biogeokémiai modell

\section{Irodalom}

BACSÓ, N., 1943. Climate classification of Hungary by Thornthwaite and vegetation geography aspects of climate maps. Időjárás. 47. 81-91.

BREUER H., 2004. A klíma és a talaj kapcsolat-rendszere Thornthwaite szempontjából. Tudományos Diákköri Dolgozat. ELTE.

Clapp, R. B. \& Hornberger, G. M., 1978. Empirical equations for some soil hydraulic properties. Water Resour. Res. 14. 601-604.

CosBY, B. J. et al., 1984. A statistical exploration of the relationships of soil moisture characteristics to the physical properties of soils. Water Resour. Res. 20. 682690.

Goudie, A., 1989. The Nature of the Environment. $2^{\text {nd }}$ ed. Basil Blackwell. Cambridge, Massachusetts.

HAYDEN, B. P., 1998. Ecosystem feedbacks on climate at the land-scape scale. Philos. Trans. R. Soc. London. Ser. B. 353. 5-18.

JuSTYÁK J. \& SzÁSz G., 2001. Az éghajlat, a növényzet, és a talaj övezetes elrendeződése a Földön. Kossuth Egyetemi Kiadó. Debrecen.

KAKAS J., 1960. A lehetséges évi evapotranspiráció. Az évi vízfölösleg. Az évi vízhiány. Magyarország Éghajlati Atlasza. Akadémiai Kiadó. Budapest.

KÖPPEN, W., 1900. Versuch einer Klassifkation der Klimate, vorzugsweise nach ihren Beziehungen zur Pflanze. Geograph. Zeitschr. 6. 593-611, 657-679.

LAmB, H. H., 1978. Climate: Present, Past, and Future - Vol. 1. Fundamentals and Climate Now. Methuen \& Co. Ltd. London.

MintZ, Y. \& SERAFINI, Y., 1981. Global fields of soil moisture and surface evapotranspiration. NASA Goddard Flight Center Tech. Memo 83907. Research Review 1980/81. 178-180.

MinTZ, Y. \& WALKER, G. K., 1993. Global fields of soil moisture and land surface evapotranspiration derived from observed precipitation and surface air temperature. J. Appl. Meteorol. 32. 1305-1335.

NEMES, A., 2003. Multi-scale hydraulic pedotransfer functions for Hungarian soils. PhD Dissertation. Wageningen University. The Netherlands.

PÉCZELY G., 1979. Éghajlattan. Tankönyvkiadó. Budapest.

Peng, C. H., GuiOt, J. \& VAN CAMPO, E., 1998. Past and future carbon balance of European ecosystems from pollen data and climatic models simulations. Global Planet Change. 18. 189-200.

PIElKE, R. A., 1998. Climate prediction as an initial value problem. Bull. Am. Meteorol. Soc. 79. 2743-2746.

RoBock, A. et al., 1998. Evaluation of the AMIP soil moisture simulations. Global Planet Change. 19. 181-208.

SEllers, W. D., 1965. Physical Climatology, University of Chicago Press. ChicagoLondon.

StefanOvits P., 1975. Talajtan. Mezőgazdasági Kiadó. Budapest. 
Stefanovits P., FileP Gy. \& FÜLeKy Gy., 1999. Talajtan. 4. kiadás átdolg. változata. (Szerk.: Stefanovits P.). Mezőgazda Kiadó. Budapest.

SzÁsz G., 1963. A vízháztartás klimatikus tényezőinek vizsgálata Magyarországon. Debreceni Agrártudományi Főiskola Tudományos Közleményei. 49-71. Debrecen.

SZEPESINÉ L. A., 1966. A Kárpát-medence hidroklímájának jellemzői. Beszámolók az 1965-ben végzett tudományos kutatásokról. Az Országos Meteorológiai Intézet hivatalos kiadványai. XXIX. 86-114.

SzESZTAY, K., 1958. Estimation of water balance of catchment areas in Hungary. Időjárás. 62. 313-328.

THORNTHWAITE, C. W., 1948. An approach toward a rational classification of climate. Geographical Rev. 38. 5-94.

VAN GenuChten, M. T., 1980. A closed-form equation for predicting the hydraulic conductivity of unsaturated soils. Soil Sci. Soc. Am. J. 44. 892-898.

VÁrALLYAY, G., 1990. Influences of climate changes on soil moisture regime, texture and erosion. In: Soils on a Warmer Earth (Eds.: ScharpenseEL, H. W., SCHOMAKeR, M. \& AyOuB, A.) 39-49. Elsevier. Amsterdam.

VÁrallyay, G., 2002. Climate change and soil processes. Időjárás. 106. 113-121.

Wang, G. \& Eltahir, L. A. B., 2000. Ecosystem dynamics and the Sahel drought. Geophys. Res. Lett. 27. 795-798.

Wösten, W. H. M. et al., 1999. Development and use of a database of hydraulic properties of European soils. Geoderma. 90. 169-185.

Zobler, L., 1986. A World Soil File for Climate Modeling. NASA Tech. Memo. 87802.

Érkezett: 2005. február 3. 


\title{
Modelling of the Relationship between Soil and Climate
}

\author{
F. ÁCS, H. BREUER, K. TARCZAY and M. DRUCZA
}

Department of Meteorology, Eötvös Loránd University, Budapest

\section{Summary}

The soil/climate relationship is mostly determined by the exchange of water and car-bon dioxide between the soil and the atmosphere. Special attention was paid to the analysis of: 1. the relationship between the climate, evapotranspiration and soil respiration, 2. the effect of climate on seasonal changes in soil respiration and 3. the effect of water holding capacity on the climate. The analysis was performed using a biogeochemical model of the Thornthwaite type, assuming that the climate, vegetation and soil are in equilibrium. The analysis was performed on both the global and local scales. In the former case a dataset referring to the whole Earth was used, in the latter one referring to Hungary. The climate data consisted of annual values of precipitation and temperature. The soil characteristics were expressed by soil texture and the corresponding hydrophysical soil parameters. The climate was expressed simply using Thornthwaite's climate formulae. The results indicated that there is an unequivocal relationship between the areal distribution of annual climatic characteristics, evapotranspiration and soil respiration. Further, it was shown that water holding capacity is a basic soil parameter, since changes in this parameter modify not only the fluxes of water vapour and carbon dioxide, but also influence the climate on both the global and local scales.

Table 1. Designations for the $1^{\text {st }}$ and $2^{\text {nd }}$ letters of the Thornthwaite climate formula. (1) $1^{\text {st }}$ letter. (2) Characterization of water supplies. a) perhumid; b) humid; c) moist subhumid; d) dry subhumid; e) semi-arid; f) arid. (3) $2^{\text {nd }}$ letter. (4) Characterization of heat supplies. g) megathermal; h) mesothermal; i) microthermal; j) tundra; k) frozen.

Table 2. Number of climate categories according to the $1^{\text {st }}$ letter of the Thornthwaite code during the three runs. (1) $1^{\text {st }}$ letter. (2) Case 1. (3) Case 2. (4) Case 3.

Figs. 1 and 2. $\mathrm{P}$ (annual precipitation, $\mathrm{mm}$ ) - T (annual mean temperature, ${ }^{\circ} \mathrm{C}$ ) diagram for Earth's climate zones (Fig. 1) and for climate zones in Hungary (Fig. 2.).

Fig.3. Relationship between annual sum of actual evapotranspiration and the Thornthwaite codes (A) and annual soil respiration and the Thornthwaite codes (B), $2^{\text {nd }}$ run.

Fig. 4. Climate of Hungary on the basis of the Thornthwaite codes (A) and the areal distribution of actual evapotranspiration (B) and soil respiration (C) for the $2^{\text {nd }}$ run.

Fig. 5. Effect of heat supplies on the annual course of soil respiration under wet (A) and dry (B) climates.

Fig. 6. Effect of water supplies on the annual course of soil respiration under warm (A) and cool (B) climates.

Fig. 7. Effect of winter $\left(\mathrm{w} / \mathrm{w}_{2}\right)(\mathrm{A})$ and summer $\left(\mathrm{s} / \mathrm{s}_{2}\right)(\mathrm{B})$ water deficiency types on the annual course of respiration.

Fig. 8. Effect of water supplies on the annual course of soil respiration in climates $\mathrm{C} 2$ and $\mathrm{C} 1$ (A), B2 and C2 (B) and C1s and C1d (C).

Fig. 9. Spatial distribution of the $1^{\text {st }}$ letter of the Thornthwaite climate formula in East Asia for the $1^{\text {st }}(\mathrm{A})$ and $3^{\text {rd }}(\mathrm{B})$ runs.

Fig. 10. Climate of Hungary on the basis of the Thornthwaite codes for the $1^{\text {st }}$ run. 